\title{
A Proposed Counseling Program to Confronting Cyberbullying among High School Students
}

\author{
Aljawharah A. Alzamil \\ Associate Professor of Social Planning, \\ College of Social Work, \\ Princess Nourah bint Abdulrahman University, \\ Airport Road, King Khalid International Airport, \\ Riyadh 11564, Saudi Arabia
}

DOI: https://doi.org/10.36941/jesr-2021-0014

\begin{abstract}
The present study aims to identify the most significant psychological, social, and community aspects of cyberbullying from the perspective of the social worker and to define the most important roles of the social worker among high school students to develop a counseling program that helps confront cyberbullying among the participants. The author developed a questionnaire to identify the most significant psychological, social, and community aspects of cyberbullying and to define the most important roles of the social worker. The author adopted the analytical-descriptive approach and applied the questionnaire to (120) social workers in public high schools in Riyadh. The results showed that the means of the community aspects were ranked first. The roles of the social worker with students, teachers, and guardians were high, suggesting the importance of these roles in handling and confront the psychological problems experienced by students. The most important roles of the social worker were used to develop the proposed counseling program to confront cyberbullying among high school students. The study recommends adopting counseling programs in handling the psychological problems among students because of their positive results in reducing such problems.
\end{abstract}

Keywords: Counseling program, Cyberbullying, High school students

\section{Introduction}

The world has recently experienced many developments in all aspects of life, including the technical ones because of the various electronic devices connected to the Internet. Although such devices have facilitated the life of people, several negative aspects have affected society, e.g. cyberbullying that has a role in intimidating and dispossessing many users of this technology. The term cyberbullying has been introduced to indicate the use of technology to harass, threaten, embarrass, or target another person. Accordingly, it mostly takes place among teenagers, especially among the students of $10^{\text {th }}-12^{\text {th }}$ grades. Furthermore, females are the most affected group by cyberbullying (Azam and Shoba, 2018). Cyberbullying is "an aggressive, intentional act carried out by a group or an individual, using electronic forms of contact, repeatedly and over time against a victim who cannot easily defend him or herself"(Pelfrey and Weber, 2014, 398). 
Examining the phenomenon shows that almost every teenager has experienced cyberbullying. Many of the cyberbullied victims prefer not to report because of fear, threat, and embarrassment, whereas others prefer to share their incidents with friends rather than parents or teachers. The impacts of cyberbullying include fear, low academic achievement, depression, loneliness, and isolation (Camacho, Hassanein, and Head, 2018). In cyberbullying, the confrontation between the bully and the victim has shifted from a direct confrontation to an indirect one that depends on a virtual environment in which the bully employs modern technology that allows social communication between the users of the Internet and smartphones to direct abuse and the repeated threat to the victim or fabricate personal scandals through anonymous accounts that inflict psychological harm on the victim in the form of text messages, websites, and penetration of personal accounts where the bully takes over personal data or photos and practices threatening and blackmailing the victim (Darwish and Allaithi, 2017).

Accordingly, cyberbullying refers to a student's intention to hurt or harm other students through online short message services using the Internet and electronic devices. Moreover, it includes cursing, insulting, humiliating, threatening, intimidating, making unwanted sexual remarks, posting private pictures, spreading rumors, and spreading a computer virus (Kiriakidis and Kavoura, 2010). Cyberbullying allows the bully to harass the victim at any time and reduces the level of responsibility and accountability of the bully than is the case in face-to-face bullying. Moreover, it does not stop once students leave school but breaks into their homes, computers, and phones (Juvonen and Gross, 2008).

There are many subcategories for cyberbullying, including text messages, bullying, pictures, video clips, and phone calls (Ibiwani, 2017). Unlike traditional bullying, cyberbullying allows the offender to mask his or her identity behind the computer and makes it easy for the offender to strike blows against victims without seeing their physical response (Johnson et al., 2016). Jun (2020) explains that the biggest type of cyberbullying among adolescents is verbal abuse, and the biggest means is instant messaging. In addition, the most frequent forms of cyberbullying victims and cyberbullying perpetrators occur between individuals. The study analyzed various cyberbullying factors, such as psychological factors. Consequently, it found that the interaction with parents and friendship reliability has a negative correlation with the cyberbullying experience rate.

Knowing that cyberbullying has become the negative side of the development of technology and information, cyberbullying prevalence was vast. Thus, a joint effort shall be taken so that the negative impact of information and technology would be minimized. Producing guidelines helps identify the characteristics of the cyberbully and the cybervictim. Moreover, understanding the factors that increase the incidence of cyberbullying requires further research (Nazriani and Zahreni, 2016). Examining the studies and reports that addressed this phenomenon shows that the development of modern electronic means of communication represented by the Internet has increased the number of electronic threats among students, including cyberbullying (Kowalski, Limber, and Agatston, 2007). Another study indicated that $(42 \%)$ of the elderly students were bullied while they were online. That percentage increased sharply in 2008 up to $(72 \%)$ in the study of Juvonen and Gross (2008).

Students have more access to technology than ever before. Pelfrey and Weber (2014) report that $(77 \%)$ of teenagers aged 12-17 years own cell phones. Teens report using their cellular devices to text, call, video chat, use social networking sites, use messengers, and e-mail. While (95\%) of all teens are online, $(80 \%)$ of them use social networking sites. Upon closer analysis, the report found that (63\%) of the daily communication for teens takes place via text messaging. Phone calls account for (39\%) of communication, (29\%) of communication was done via messengers on social networking sites, (22\%) via instant messaging, and (35\%) were in-person outside of the school. These prevalence rates have implications for cyberbullying because increased screen time means that the likelihood of cyberbullying also increases (Pelfrey and Weber, 2014).

Cyberbullying is not limited to a specific place or field. It happens inside and outside the school and challenges the entire education system, including teachers, students, parents, and policymakers (Gamrawi, Gamrawi, and Shal, 2016). It has multiple and various effects that include poor health, low academic performance, isolation, loss of friendship (Cassidy, Faucher, and Jackson, 2017), as well as depression, and lower self-esteem (Selkie, Kota, Chan, and Moreno, 2015). 
Cyberbullying depends on the web environment that is characterized by openness and massive spread, the chances of concealment available to the bully, and the lack of direct confrontation with the victim. Consequently, the bully can cause frequent harm to victims psychologically and socially at a high speed through websites and social media. Moreover, the victims are exposed to negative experiences that contribute to wasting their energies and low academic achievement (Darwish and Allaithi, 2017).

Burton, Florell, and Gore (2013) point out that cyberbullying is distinctive in that the damage it inflicts is, in most cases, psychological and it occurs wherever the student has access to technology. That is, it may not necessarily be escapable. The ability to copy and paste or share something that another person has said is also a distinctive feature of cyberbullying because of the ease at which technology allows information to spread. Cyberbullying has the potential to infiltrate the lives of the victims twenty-four hours a day and involves an instant and ever-expanding audience (Compton, Campbell, and Mergler, 2014). Waasdorp, Bradshaw, and Leaf (2012) conducted a study on cyberbullying among high school students and found that students tend to think that the person who cyberbullies them is a friend of theirs, even if they are not sure of his/ her identity.

The frequency of experiencing cyberbullying appears to fluctuate according to the literature. For example, Li (2006) reported a high incidence rate with (54.9\%) experiencing cyberbullying approximately 4 times, (20.3\%) experiencing this 4 -1otimes, and (21.1\%) of them experiencing cyberbullying more than 10 times. The frequency of committing the abuse was also high with (20.7\%) of participants are committing cyberbullying more than 10 times, (43.\%) are doing it 4-10 times, and (30.5\%) are doing it less than (4) times. Li (2010) reported that over (40\%) of the participants would do nothing if they were cyberbullied, and only 1 in 10 would inform adults. Students feel reluctant to report cyberbullying incidents to adults in schools for various reasons. Safaria (2016) showed that most of the participants reported experiencing cybervictimization occasionally.

Chen (2018) indicated that $(17.8 \%)$ of the students reported cyberbullying, whereas (30.9\%) experienced at least one type of cyberbullying in the past three months. Moreover, curses, insults, and humiliation were the most common types of cyberbullying. Males reported higher rates of bullying and victimization than did females. A 2016 report of the Cyberbullying Research Center warned that about $50 \%$ of the teenagers who use a cell phone regularly have experienced some form of cyberbullying.

Previous international studies suggested that high school students are more vulnerable to cyberbullying than elementary school or university students. These studies also indicated the importance of investigating the prevalence of cyberbullying by gender and grade level among high school students when designing policies for tackling cyberbullying (Smith et al., 2008). However, student cyberbullying is serious because some reports suggested that high school students spend more time on the Internet, which may increase the risk of cyberbullying. The rate of cyberbullying increases with age through childhood and adolescence, leading to a greater problem in high school.

Makanin, Younis, and Hayari (2017) revealed that the level of cyberbullying among students was high. There were differences in cyberbullying levels among students according to gender in favor of the males. Johnson et al. (2016) confirmed that cyberbullying is very high among high school students in the United States of America. This finding was confirmed by Moses (2013) that cyberbullying is a real problem among high school students. In contrast, Abdul-Qadir and Al-Rimawi (2019) showed that the level of cyberbullying among high school students was low, while the level of motivation for academic achievement was average. Moreover, Hashem (2019) reported that the prevalence of cyberbullying among high school students was moderate as they practiced many forms of cyberbullying, including ridiculing by polling, defaming a person through rumors, publishing wrong information or annoying images, harassment, repeated insults, impersonation, disclosure of secrets, and cyberharassment. Cyberbullying has drawn growing interest due to its devastating effects that led some students to suicide, the awareness of the parents about the phenomenon, and the media role to raise awareness about cyberbullying (Bhnasawi \& Hasan, 2015)

Regarding the seriousness and importance of this phenomenon, several studies, such as Alwan (2016), emphasized the importance of designing counseling programs for adolescents by limiting 
aggressive behaviors. Thus, counseling programs should be developed to satisfy the counseling and cognitive needs of students and to handle the social, psychological, and academic problems of bullying. The author perceived this problem due to the prevalence of violence and aggression among students, especially adolescents. This finding was confirmed by many studies across Saudi Arabia. For instance, Al-Qahtani(2008) found a widespread phenomenon among students in public and private schools in Riyadh. Khoj (2012) showed that the factors of skills that contribute to predicting school bullying were the social, emotional, social factors, respectively. Mustafa (2017) showed the main motifs for the practice of cyberbullying among students in the Eastern Province of Saudi Arabia. Moreover, Albentan (2019) revealed the degree of the availability of social factors leading to the practice of second-graders' behavior of bullying.

From the previous presentation of the related literature and the seriousness of the phenomenon of cyberbullying, the author finds that the studies in the Kingdom of Saudi Arabia are not a lot enough compared to the size of the problem. Thus, she argues for the importance of studying the various aspects of this serious phenomenon among high school students. Cyberbullying is a serious behavior that has emerged through the negative interaction of some adolescents with modern technology and communication tools. This problem can threaten the future of students at this critical age because Arab society suffers from a real lack of knowledge of this problem. The present study highlights the size of the phenomenon and explores its psychological, social, and community aspects among high school students in Riyadh. It also reveals the reasons and motifs for the spread of this phenomenon. Moreover, it develops a counseling program to confront this problem among high school students in Saudi Arabia.

\section{$1.1 \quad$ Questions}

The present study tries to answer the following questions:

1. What are the psychological, social, and community aspects of cyberbullying among high school students from the perspective of the social worker?

2. What is the role of the social worker in confronting and handling cyberbullying among high school students from their perspective?

3. What is the proposed counseling program to confront cyberbullying among high school students?

\subsection{Objectives}

1. Define the psychological, social, and community aspects of cyberbullying among high school students.

2. Identify the role of the social worker in confronting and handling cyberbullying among high school students.

3. Develop a proposed counseling program to confront cyberbullying among high school students.

\subsection{Significance}

1. High school is a stage of the completion of the physical and mental development of the student and needs special treatment for students. In this stage (adolescence), the manifestations of (verbal, actual, and physical) violence have a significant impact on the adolescent.

2. Bullying is a common and serious problem in the school community. However, it did not receive adequate attention in the Arab world. The present study investigates the causes and provides solutions. In contrast, foreign literature is rich in books, researches, and journals in this regard that there are institutes specialized in combating bullying in schools.

3. A counseling program should be designed to confronted cyberbullying among high school 
students.

4. The present study may be a starting point to confront cyberbullying among high school students with its suggestions and recommendations. It may help educators, in general, and student counseling, in particular, carry out their work professionally to meet the challenges of high school, including bullying among adolescent students.

5. It is an intervention study based on the intervention of a phenomenon using the counseling program to modify the behavior of cyberbullying.

6. It fits in cyberpsychology that examines human phenomena resulting from human interaction with the internet-related emerging technology.

\subsection{Limitations}

\section{Subject limitations:}

- A set of aspects related to cyberbullying, namely the psychological, social, and community

- Some roles of the social worker in confronting cyberbullying, namely role with students and role with teachers and guardians

Spatial limitations: Public high schools in Riyadh

Human limitations: Students enrolled in public high schools in Riyadh

Temporal limitations: The study was applied in the second semester of 2019/2020.

\subsection{Definition of Terms}

- Counseling Program:

The American Psychological Association defines it as that service that aims to help individuals acquire and develop personal and social skills, improve compatibility with changing life demands, and enhance successful coping skills with the environment.

It is procedurally defined as a program developed according to scientific bases to provide consulting services to the high school students to confront cyberbullying and its psychological, social, and community aspects. It includes counseling sessions and uses various techniques, methods, tools, and means to achieve its objectives.

- Cyberbullying:

The American Psychological Association (2015) defines cyberbullying as a "verbally threatening or harassing behavior conducted through such electronic technology as cell phones, e-mail, and text messaging" (p. 149).

Cyberbullying is procedurally defined as remote harassments using technological communication means by the bully against the victim at high school to cause several psychological, social, and community impacts. It is measured by the developed questionnaire from the perspective of the social worker.

- High school students:

They are procedurally defined as the victims of cyberbullying of high school students in Riyadh to whom the counseling program was applied to reduce the psychological, social, and community impacts of cyberbullying.

\section{Methodology}

\subsection{Method}

The author adopted the analytical descriptive approach because of its appropriateness to the topic and objectives of the study by an accurate description of the phenomenon quantitatively and qualitatively, discussion, and analysis to conclude facts about the dominant social conditions to make major 
developmental changes (Abu Allam, 2010; Abu Hatab and Sadek, 2010). The author reviewed the literature and collected and analyzed data by studying the psychological, social, and community aspects of cyberbullying among high school students from the perspectives of the social workers using a questionnaire. Then, the perspectives of the social workers were surveyed about their roles in confronting the phenomenon among high school students. After that, statistical analysis was carried out, and results were analyzed and discussed to develop a proposed program for confronting cyberbullying.

\subsection{Population and sampling}

The population covered all female social workers at high school students in Riyadh in the second semester of 2019/2020. The sample comprised (120) female social workers aged 30-40 years and more who were randomly selected. To illustrate the demographic features, the study included three independent variables related to preliminary data, i.e., age, years of experience, and taking workrelated training courses.

Table (1): Distribution and percentage of the sample according to the variables

\begin{tabular}{|l|l|c|c|}
\hline Variable & Frequency & Percentage \\
\hline \multirow{4}{*}{ Age } & 30 to less than 35 years & 41 & $33.2 \%$ \\
\cline { 2 - 4 } & 35 to less than 40 years & 69 & $57.5 \%$ \\
\cline { 2 - 4 } & 45 years and more & 10 & $8.3 \%$ \\
\cline { 2 - 4 } & Total & 120 & $100 \%$ \\
\hline \multirow{4}{*}{ Years of experience } & $3-5$ years & 39 & $32.5 \%$ \\
\cline { 2 - 4 } & $6-8$ years & 53 & $44.2 \%$ \\
\cline { 2 - 4 } & More than 8 years & 28 & $23.3 \%$ \\
\cline { 2 - 4 } & Total & 120 & $100 \%$ \\
\hline \multirow{3}{*}{ Taking work-related training courses } & Yes & 31 & $\mathbf{2 4 . 2} \%$ \\
\cline { 2 - 4 } & No & 120 & $100 \%$ \\
\cline { 2 - 4 } & Total & & \multicolumn{2}{|c}{} \\
\hline
\end{tabular}

Table (1) shows the distribution of the three variables. The age group ( 35 to less than 40 years) was rated $57.7 \%$, the age group (30 to less than 35 years) was rated $33.2 \%$, and ( 45 years and more) was rated $8.3 \%$. In the years of experience, $(6-8)$ was rated $44.2 \%$, (3-5) was rated $32.5 \%$, and (more than 8 ) was rated $(23.3 \%)$. Moreover, most of the participants $(74.2 \%)$ took training courses.

\subsection{Tool}

The author employed a 51-item questionnaire to identify the psychological, social, and community aspects of cyberbullying among high school students and the role of the social worker in its confrontation using a closed three-point Likert scale (agree- undecided- disagree). She reviewed the relevant literature, such as Abdelaziz (2014), Albentan (2019), Hasan (2020), and Refaey (2016). The preliminary form of the questionnaire was presented to (5) reviewers in psychology and mental health. In the light of their views, modifications were made by eliminating some items and adding others. The final form of the questionnaire comprised two sections. While Section one covered the personal data (age, years of experience, and training courses), section two consisted of (51) items distributed to two themes. Theme one "aspects of cyberbullying) consists of three domains: Psychological aspects (12 items), social aspects (6 items), and community aspects (6 items). Theme two "the role of the social worker in cyberbullying confrontation" comprises two domains: The role of the social worker with students (19 items) and the role of the social worker with teachers and guardians (8 items). 


\section{$2.4 \quad$ Scaling}

Scores were scaled on a three-point Likert scale: Agree (3), undecided (2), and disagree (1). The score (1-1.66) is weak, (1.67-2.33) is moderate, and (2.34-3) is high.

\subsection{Validity}

- Face validity: After reviewing the preliminary form of the questionnaire by (5) reviewers in psychology and mental health, modifications were made, and the final questionnaire was valid.

- Content validity: The correlation coefficients between each domain and the total score of the questionnaire were estimated after application to a pilot sample of (15) social workers (outside the sample). They were high, as shown in table (2).

Table (2): Correlation coefficients between each domain and the total score of the questionnaire

\begin{tabular}{|l|c|}
\hline Psychological aspects & $0.83^{* *}$ \\
\hline Correlation coefficient & $0.8 \mathrm{O}^{* *}$ \\
\hline Social aspects & $0.79^{* *}$ \\
\hline Correlation coefficient & $0.87^{* *}$ \\
\hline Community aspects & \\
\hline Correlation coefficient & $0.84^{* *}$ \\
\hline The role of the social worker with students \\
\hline Correlation coefficient & \\
\hline The role of the social worker with teachers and guardians & \\
\hline Correlation coefficient &
\end{tabular}

$\left.{ }^{* *}\right)$ Significant at the level of 0.01

Table (2) shows that the correlation coefficients between each domain and the total score of the questionnaire are statistically significant at the level of (o.o1), indicating content validity.

\subsection{Reliability}

The author used Cronbach's alpha to calculate the reliability of the tool, see table (3).

Table (3): Values of the reliability of the questionnaire and its domains

\begin{tabular}{|l|c|}
\hline Tool & Cronbach's alpha \\
\hline Total score of the tool & $0.92^{\star *}$ \\
\hline Psychological aspects & $0.89^{* *}$ \\
\hline Social aspects & $0.87^{* *}$ \\
\hline Community aspects & $0.90^{* *}$ \\
\hline The role of the social worker with students & $0.93^{* *}$ \\
\hline The role of the social worker with teachers and guardians & $0.92^{* *}$ \\
\hline
\end{tabular}

$(* *)$ Significant at the level of 0.01

Table (3) illustrates that all reliability coefficients are significant at the level of (o.o1), showing the high reliability of the tool.

\section{Results and Discussion}

1. To answer the first question, the frequency, rank, relative weight, and percentage of the responses were calculated, as shown in table (4). 
Table (4): Psychological, social, and community aspects of cyberbullying among high school students from the perspective of the social worker

\begin{tabular}{|c|c|c|c|c|c|c|c|c|}
\hline \multirow{3}{*}{ 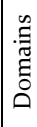 } & \multirow{3}{*}{ Item } & \multicolumn{7}{|c|}{ Sample } \\
\hline & & \multicolumn{3}{|c|}{ Frequency } & \multirow{2}{*}{$\begin{array}{c}\text { Relative } \\
\text { weight }\end{array}$} & \multirow{2}{*}{$\%$} & \multirow{2}{*}{ Rank } & \multirow{2}{*}{$\begin{array}{c}\text { Arithmetic } \\
\text { means }\end{array}$} \\
\hline & & Agree & Undecided & Disagree & & & & \\
\hline \multirow{12}{*}{ 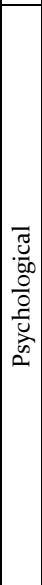 } & Cyberbullying causes depression and frustration to the victims. & 101 & 7 & 12 & 329 & 91.38 & 7 & \multirow{12}{*}{91.54} \\
\hline & Bullied students feel fear and anxiety from new things. & 98 & 15 & 7 & 331 & 91.94 & 6 & \\
\hline & Cyberbullying causes sleep and eating disorders to the victims. & 90 & 14 & 16 & 314 & 87.22 & 8 & \\
\hline & Bullied students think about suicide. & 90 & 5 & 25 & 305 & 84.72 & 9 & \\
\hline & $\begin{array}{l}\text { Cyberbullying causes anxiety, chronic fear, and insecurity to the } \\
\text { victim. }\end{array}$ & 103 & 16 & 1 & 342 & 95 & 3 & \\
\hline & $\begin{array}{l}\text { Cyberbullying causes depression, trouble, and confusion to the } \\
\text { bullied students. }\end{array}$ & 105 & 10 & 5 & 340 & 94.44 & 4 & \\
\hline & Cyberbullying weakens the self-confidence of the bullied. & 113 & 5 & 2 & 351 & 97.5 & 1 & \\
\hline & $\begin{array}{l}\text { Cyberbullying makes the bullied students unable to form their } \\
\text { skills. }\end{array}$ & 111 & 6 & 3 & 348 & 96.66 & 2 & \\
\hline & $\begin{array}{l}\text { Cyberbullying causes psychosomatic manifestations, e.g. } \\
\text { headache and stomach. }\end{array}$ & 90 & 5 & 25 & 305 & 84.72 & 9 & \\
\hline & $\begin{array}{l}\text { Cyberbullying motivates the victims to plan to cause harm and } \\
\text { take revenge from the bully. }\end{array}$ & 83 & 19 & 18 & 305 & 84.72 & 9 & \\
\hline & $\begin{array}{l}\text { Cyberbullying makes the victims feel humiliated, dissatisfied, } \\
\text { and doubtful about their value and personality. }\end{array}$ & 108 & 12 & o & 348 & 96.66 & 2 & \\
\hline & $\begin{array}{l}\text { Cyberbullying makes the victims unhappy because of the guilt } \\
\text { of not defending themselves. }\end{array}$ & 103 & 11 & 6 & 337 & 93.61 & 5 & \\
\hline \multirow{6}{*}{ 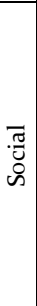 } & Cyberbullying makes the victim feel difficult to trust others. & 115 & 5 & o & 355 & 98.61 & 1 & \multirow{6}{*}{90.32} \\
\hline & $\begin{array}{l}\text { Cyberbullying makes the victim withdraw from social activities } \\
\text { in family and school. }\end{array}$ & 91 & 15 & 14 & 317 & 88.05 & 4 & \\
\hline & $\begin{array}{l}\text { Cyberbullying makes the bullied students reluctant to make } \\
\text { new friends. }\end{array}$ & 90 & 5 & 25 & 305 & 84.72 & 6 & \\
\hline & Cyberbullying makes the bullied students aggressive. & 89 & 12 & 19 & 310 & 86.11 & 5 & \\
\hline & $\begin{array}{l}\text { Cyberbullying makes the bullied students reluctant to speak to } \\
\text { others. }\end{array}$ & 99 & 8 & 13 & 326 & 90.55 & 3 & \\
\hline & $\begin{array}{l}\text { Cyberbullying makes the bullied students reluctant to solve } \\
\text { problems because of the difficulty of making decisions. }\end{array}$ & 103 & 12 & 5 & 338 & 93.88 & 2 & \\
\hline \multirow{6}{*}{ 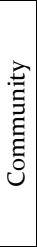 } & $\begin{array}{l}\text { Cyberbullying increases school drop-out and absence and } \\
\text { affects the future of education. }\end{array}$ & 95 & 7 & 18 & 317 & 88.05 & 5 & \multirow{6}{*}{92.45} \\
\hline & Cyberbullying disseminates conflicts and violence in society. & 112 & 7 & 1 & 351 & $97 \cdot 5$ & 3 & \\
\hline & Cyberbullying often violates the basic standards of human justice. & 117 & 3 & o & 357 & 99.16 & 1 & \\
\hline & $\begin{array}{l}\text { Cyberbullying causes family problems, including family } \\
\text { breakdown. }\end{array}$ & 82 & 4 & 34 & 288 & 80 & 6 & \\
\hline & Cyberbullying disseminates racism. & 115 & 3 & 2 & 353 & 98.05 & 2 & \\
\hline & Cyberbullying causes damages to educational investments. & 100 & 11 & 9 & 331 & 91.94 & 4 & \\
\hline
\end{tabular}

Table (4) shows that the most significant psychological aspects of cyberbullying among the victims of the high school students are weak self-confidence, humiliation and despise, inability to develop skills, as well as chronic fear, insecurity, and anxiety. The most significant social aspects include the difficulty of trusting others, the reluctance to solve problems, and the reluctance to speak to others. Moreover, the highest community aspects are violating the basic standards of human justice, the dissemination of racism, and the dissemination of conflicts and violence.

The author argues that cyberbullying is a growing school problem and takes many physical, verbal, social, and sexual forms. Consequently, the victims have experienced several psychological problems. Modern technology helps the bully access the victim anytime in private or public. Thus, the victims may drop out of school or withdraw from school activities. Socially, the victim may not trust the members of the society and doubt the surrounding people as the source of nuisance. In the case of the lack of intervention, the problem becomes a social issue, disseminates conflicts and racism, and affects the security, psychological, and social aspects of the society. This finding agrees with Danielle (2015) and Ismail (2010). 
2. To answer the second question, the frequency, rank, relative weight, and percentage of the responses were calculated, as shown in table (5).

Table (5): The role of the social worker in confronting and handling cyberbullying

\begin{tabular}{|c|c|c|c|c|c|c|c|c|}
\hline \multirow{3}{*}{$\frac{\mathscr{q}}{0}$} & \multirow{3}{*}{ Items } & \multicolumn{7}{|c|}{ Sample } \\
\hline & & \multicolumn{3}{|c|}{ Frequency } & \multirow{2}{*}{$\begin{array}{c}\text { Relative } \\
\text { weight }\end{array}$} & \multirow{2}{*}{$\%$} & \multirow{2}{*}{ Rank } & \multirow{2}{*}{$\begin{array}{c}\text { Arithmetic } \\
\text { means }\end{array}$} \\
\hline & & Agree & Undecided & Disagree & & & & \\
\hline \multirow{19}{*}{ 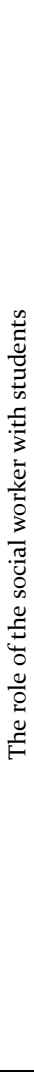 } & $\begin{array}{l}\text { Developing cultural programs to promote students' religious } \\
\text { awareness and good morals }\end{array}$ & 113 & 7 & o & 353 & 98.05 & 2 & \multirow{19}{*}{93} \\
\hline & Helping students make friends based on love and good friendship & 91 & 15 & 14 & 317 & 88.05 & 14 & \\
\hline & $\begin{array}{l}\text { Continuous follow-up of student behaviors and reducing any } \\
\text { wrong ones }\end{array}$ & 93 & 18 & 9 & 324 & 90 & 13 & \\
\hline & Providing various programs and activities to spend free time & 89 & 19 & 12 & 317 & 88.05 & 14 & \\
\hline & $\begin{array}{l}\text { Raising student awareness of the negative impacts of watching } \\
\text { violent games and movies }\end{array}$ & 109 & 5 & 6 & 343 & 95.27 & 6 & \\
\hline & $\begin{array}{l}\text { Exploring individual cases of cyberbullying to make treatment } \\
\text { plans }\end{array}$ & 100 & 15 & 5 & 335 & 93.05 & 8 & \\
\hline & $\begin{array}{l}\text { Holding symposia and delivering lectures to introduce the } \\
\text { concept of cyberbullying and its confrontation }\end{array}$ & 101 & 11 & 8 & 333 & 92.5 & 9 & \\
\hline & \begin{tabular}{|l|l} 
Teaching students defense educational means and confrontation \\
\end{tabular} & 105 & 11 & 4 & 341 & 94.72 & 7 & \\
\hline & $\begin{array}{l}\text { Holding awareness activities on cyberbullying to discover cases } \\
\text { and encourage students to seek help }\end{array}$ & 111 & 7 & 2 & 349 & 96.94 & 4 & \\
\hline & Equipping students with the culture of the safe use of the Internet & 99 & 15 & 6 & 333 & 92.5 & 9 & \\
\hline & $\begin{array}{l}\text { Training students in relaxation techniques to confront difficult } \\
\text { situations }\end{array}$ & 91 & 25 & 4 & 327 & 90.83 & 11 & \\
\hline & $\begin{array}{l}\begin{array}{l}\text { Having serious discussions with students to introduce the sources } \\
\text { of support when experiencing cyberbullying }\end{array} \\
\end{array}$ & 112 & 8 & $\mathrm{o}$ & 352 & $97 \cdot 77$ & 3 & \\
\hline & $\begin{array}{l}\text { Guiding students to the participation in social activities that fit } \\
\text { their interests to improve self-confidence and social skills }\end{array}$ & 109 & 10 & 1 & 348 & 96.66 & 5 & \\
\hline & $\begin{array}{l}\text { Training students in life skills, e.g. sympathy, tolerance, peaceful } \\
\text { coexistence }\end{array}$ & 107 & 11 & 2 & 345 & 95.83 & 6 & \\
\hline & $\begin{array}{l}\text { Holding public religious symposia to illustrate the Islamic } \\
\text { situation from bullying }\end{array}$ & 115 & 5 & o & 355 & 98.61 & 1 & \\
\hline & $\begin{array}{l}\text { Applying cyberbullying scales to students to identify the spread of } \\
\text { the phenomenon }\end{array}$ & 100 & 11 & 9 & 331 & 91.94 & 10 & \\
\hline & $\begin{array}{l}\text { Designing an educational program for high school students of } \\
\text { digital citizenship and the ethical use of technology by recruiting } \\
\text { educational experts and specialists }\end{array}$ & 87 & 15 & 18 & 309 & 85.83 & 15 & \\
\hline & $\begin{array}{l}\text { Meeting the psychological and social needs of the students that } \\
\text { cause cyberbullying }\end{array}$ & 95 & 15 & 10 & 325 & 90.27 & 12 & \\
\hline & $\begin{array}{l}\text { Preparing disciplinary records of the bullies and maintaining their } \\
\text { privacy }\end{array}$ & 97 & 11 & 12 & 325 & 90.27 & 12 & \\
\hline \multirow{8}{*}{ 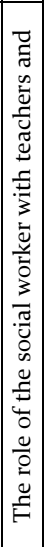 } & $\begin{array}{l}\text { Holding regular symposia and meetings with the guardians to } \\
\text { develop the methods of treating cyberbullying }\end{array}$ & 104 & 7 & 9 & 335 & 93.05 & 4 & \multirow{8}{*}{92.63} \\
\hline & $\begin{array}{l}\text { Holding training courses for the teachers to introduce the most } \\
\text { significant counseling means for confronting cyberbullying }\end{array}$ & 103 & 11 & 6 & 337 & 93.61 & 3 & \\
\hline & $\begin{array}{l}\text { Making pamphlets for the teachers and guardians to explain the } \\
\text { meaning, confrontation, and treatment of cyberbullying }\end{array}$ & 99 & 10 & 11 & 328 & 91.11 & 6 & \\
\hline & $\begin{array}{l}\text { Activating the educational role of mothers' councils to link school } \\
\text { to home and handle cyberbullying cases }\end{array}$ & 111 & 7 & 2 & 349 & 96.94 & 2 & \\
\hline & $\begin{array}{l}\text { Holding counseling seminars to raise the awareness of guardians } \\
\text { about the dangers of this age group (adolescence) an helping } \\
\text { them employ the appropriate educational styles. }\end{array}$ & 89 & 14 & 17 & 312 & 86.66 & 8 & \\
\hline & $\begin{array}{l}\text { Educating guardians about sound parental methods to promote } \\
\text { self-confidence among students }\end{array}$ & 90 & 23 & 7 & 323 & 89.72 & 7 & \\
\hline & $\begin{array}{l}\text { Guiding guardians to follow up their children and highlight any } \\
\text { changes }\end{array}$ & 112 & 7 & 1 & 351 & 97.5 & 1 & \\
\hline & $\begin{array}{l}\text { Holding meetings with teachers and guardians on the methods } \\
\text { and means to be adopted with bullies and focusing on positive } \\
\text { reinforcement }\end{array}$ & 102 & 9 & 9 & 333 & 92.5 & 5 & \\
\hline
\end{tabular}


Table (5) shows that the highest roles of social workers with students are holding public religious symposia to illustrate the Islamic situation from bullying, developing cultural programs to promote students' religious awareness and good morals, and having serious discussions with students to introduce the sources of support when experiencing cyberbullying. The highest roles of the social worker with teachers and guardians are guiding guardians to follow up their children and highlight any changes, activating the educational role of mothers' councils to link school to home and handle cyberbullying cases, and holding training courses for the teachers to introduce the most significant counseling means for confronting cyberbullying. The author argues that the most significant roles of the social workers are treatment ones, indicating their high awareness about the phenomenon and well-preparation. The Saudi society is Islamic and the Islamic symposia motivate the student to master self-control and good morals. Thus, students can handle cyberbullying. The social workers play an important role with the teacher because of their awareness about cooperating with teachers and guardians to handle cyberbullying. The roles of the social workers with students and teachers and guardians were rated (93\%) and (92.63\%), respectively. Therefore, they uniquely practice their expected roles. While this finding agrees with Mohamed (2018), it differs from Abdelaziz (2014).

3. Answer to the third question

The literature showed that professional intervention using a counseling program is more effective in the work of social workers to reduce and confront the manifestations of bullying based on the contents, sessions, and techniques of the counseling program. To motivate participation, various means were used, such as discussion, roleplay, homework, worksheets, modeling, and imagination. Different activities can help enhance motivation and benefit from the counseling program in reducing bullying. Therefore, the author developed the proposed counseling program for confronting cyberbullying among high school students.

Program Description: It is a program of cyberbullying confrontation developed on scientific bases. It is developed because of the spread of cyberbullying that has caused psychological, social, and community aspects. It helps train in the safe use of the Internet, the appropriate skills of problemsolving, and the educational means of self-defense to achieve compatibility and self-adjustment. It comprises (18) counseling sessions, and each session handles a certain behavior in an integrative manner while using multiple techniques, methods, tools, and means.

Philosophical bases of the program

Any counseling program relies on a theoretical basis according to guidance and counseling theories that adopt a certain perspective, including the cognitive, behavioral, psychoanalytic, or humanistic theory. It should have the following bases

- Compatibility of the program objectives with the general education objectives

- Creating a safe learning environment

- Providing the capabilities for the success of the program in terms of planning, implementation, evaluation, and follow-up

The author adopted cognitive-behavioral counseling that relies on behavior modification by focusing on the perception of environmental stimuli. This approach modifies cognitive structure and misconceptions.

Method of the program

The program uses group counseling because of its several benefits and advantages as it benefits the largest group of students with less cost and time. Group counseling fits the program because of the nature of the students understudy who tend to make friends and adopt teamwork. Moreover, cyberbullying with its serious psychological and social aspects, including depression and anxiety, affects the emotional, social, and academic development of the individual. In group counseling, assisting students to help themselves can be more effective because the participants make several suggestions that may benefit students indirectly.

The general objective of the program: The proposed counseling program aims to empower high school students (victims of bullying) to confront cyberbullying by resolving the psychological, social, 
and community aspects.

Special objectives of the program:

After applying the program, the student is expected to:

- Identify the concept of cyberbullying.

- Define the various forms and methods of cyberbullying.

- Define the causes of cyberbullying.

- Discuss the challenges encountered by the victims of cyberbullying.

- Identify the psychological impacts and aspects of cyberbullying.

- Identify the social impacts and aspects of cyberbullying.

- Identify the community impacts and aspects of cyberbullying.

- Apply the different strategies of confronting cyberbullying.

- Identify the means of avoiding cyberbullying.

Basics of formulating the content of the program

1. The nature of the high school students (teenagers) who experience physiological, emotional, and mental changes in this age group

2. The nature of the Saudi society in which the student lives in addition to family socialization with its several ideas that affect the behavior of cyberbullying

3. Relying on activities in the program because of its ability to attract students to the various cognitive aspects

4. Interest in the religious principles of confronting cyberbullying because students respect the Islamic values

\section{Content of the program}

To prepare an appropriate content of the program, the author reviewed the relevant literature, especially the studies with cyberbullying-related counseling programs, e.g., Abu-alela (2017), Aly (2017), Guckin et al. (2013), Hussein (2019), Mohamed (2018), Mohamed and Mohamed (2017), and Šléglová and Cerna (2011) to identify and employ the components and steps of the program. These studies highlighted using seminars, regular meetings, presentations, discussions, and dialogs, as well as translating the counseling sessions into applicable action ones. Activities and tasks developed in the light of the literature were distributed to all sessions. Then, the worksheets of the sessions and the homework including the activity and its steps using certain techniques were developed. The program, worksheets, and activities were presented to a group of reviewers to verify their validity. The reviewers gave opinions on the content, techniques and activities, appropriateness of the content, adequacy of the timing, and the session's content and time, as well as evaluation styles of the program. They agreed on $(85 \%)$ of the program. After eliminating, adding, and modifying some items, the final form of the counseling program was made.

The roles of the social worker in the counseling program

1. As an educator, a social worker modifies some misconceptions of high school students related to cyberbullying and provides information on their characteristics, problems, and impact on their behaviors, relationships, and interactions. A social worker also modifies the misconceptions that hinder cyberbullying confrontation.

2. As a psychologist, a social worker defines some weak aspects of the personality of high school students and the skills of confronting cyberbullying, develops programs and activities to develop such skills, and help students modify their skills and handle the cyberbullying situations they experience.

3. As a counselor, a social worker guides high school students in their relationships and interactions to modify the behaviors related to cyberbullying.

4. As a planner, a social worker carries out activities and programs to prioritize tasks and responsibilities based on examining the real characteristics, weaknesses, resources, and capabilities of high school students to develop the skills of cyberbullying confrontation.

5. As a data collector, a social worker collects data on the factors affecting the personalities and 
behaviors of high school students during the cyberbullying confrontation, as well as the resources and capabilities of the social institution and local community to develop these skills among students.

Tools and means of the program: Computers, data shows, worksheets, colored pencils, paintings, photos, session assessment form, and program assessment form.

Techniques, methods, and strategies of implementing the counseling program: Lecture, open discussion, narration, video-based therapy, homework, cognitive restructuring, self-direct talk, assertive training, succession when confronting a situation of a problem, modeling, intermittent and hard reinforcement, roleplay, self-reassurance, relaxation, survey, and cooperative learning, as follows:

1. Lecture and open discussion: The counselor plays the role of the leader by delivering a lecture or managing a discussion and may seek the help of an expert. In this technique, a participant receives information on defining, understanding, and resolving the problem.

2. The cognitive restructuring aims to modify the thinking styles of students based on rationalemotive therapy. It helps enhance the positive thinking and optimism of the individual. It helps the student identify and modify the irrational beliefs.

3. Self-directed talk: The counselor identifies and modifies the negative self-talk of the students to enhance self-confidence.

4. Assertive training focuses on a set of purposeful behavioral-cognitive methods and procedures of modifying student behaviors and training them in self-expression and defending their rights.

5. Succession when confronting a situation of a problem includes stop and think before acting, identify the problem, develop alternative solutions, evaluate potential implications, choose, and carry out the solution.

6. Narration, modeling, and roleplay: The counselor prepares an anecdote on some issues and events similar to the behavioral problems of the students. Then, group discussion is allowed, and roles are played based on student desires. Modeling involves a certain behavior by observing the behavior of a model according to certain instructions.

7. Reinforcement: A stimulus is recalled, and the desired response is repeated.

8. Relaxation: It reduces the symptoms of bullying by developing self-esteem and creating an atmosphere of psychological-emotional relaxation.

9. Homework from simple to complex

Program evaluation

a. Formative evaluation is provided in each stage, and feedback is offered. It covers evaluating the outcomes of high school students, the performance of the social workers, and the program strategies.

b. Summative evaluation: It helps make a decision on the effectiveness, improvement, and generalization of the program.

Timeline of the program: The program includes (18) training sessions over (6) weeks; (3) sessions a week. The session is 50 to 60 minutes at the library and the computer room, as shown in table (6).

The general framework of the proposed counseling program

Table (6): Outline of the sessions, as well as their objectives, techniques, and timeline of the proposed counseling program

\begin{tabular}{|c|l|l|l|}
\hline Session & Topic & Objectives & Targeted groups \\
\hline 5 & Introductory session & $\begin{array}{l}\bullet \text { Get acquainted and build trust and familiarity between } \\
\text { the social worker (as a guide) and high school students } \\
\text { and among students } \\
\text { - Set the work and behavioral rules of the sessions, their } \\
\text { places, and timing }\end{array}$ & $\begin{array}{l}\text { Lecture- Open discussions- } \\
\text { Reinforcement }\end{array}$ \\
\hline $\begin{array}{l}\text { Introducing the counseling } \\
\text { program }\end{array}$ & $\begin{array}{l}\text { Introduce the program, basics, contents, and objectives } \\
\text { Introduce the roles and responsibilities of the social } \\
\text { worker and students } \\
\text { Discuss the expected results with students }\end{array}$ & $\begin{array}{l}\text { Lecture- Open discussions- } \\
\text { Brainstorming- Reinforcement }\end{array}$ \\
\hline
\end{tabular}




\begin{tabular}{|c|c|c|c|c|}
\hline \begin{tabular}{|l|} 
Session \\
\end{tabular} & Topic & Objectives & Targeted groups & Timing \\
\hline Е & $\begin{array}{l}\text { Cyberbullying: Concept, } \\
\text { forms, and benefits of } \\
\text { stopping it }\end{array}$ & $\begin{array}{l}\text { - Define the concept of cyberbullying } \\
\text { - Illustrate the forms of cyberbullying } \\
\text { - Introduce the benefits of stopping such bad behaviors }\end{array}$ & $\begin{array}{l}\text { Lecture- Open discussions- Cognitive } \\
\text { restructuring- Reinforcement- } \\
\text { Homework }\end{array}$ & $\begin{array}{c}5^{0} \\
\text { minutes }\end{array}$ \\
\hline 冚 & $\begin{array}{l}\text { Islam and cyberbullying } \\
\text { and its supporting } \\
\text { environments }\end{array}$ & $\begin{array}{l}\text { - Introduce the situation of Islam of cyberbullying and the } \\
\text { various forms of violence } \\
\text { - Cite Qur'anic evidence and Prophetic Hadith that } \\
\text { prohibit cyberbullying } \\
\text { - Introduce the environments that support cyberbullying }\end{array}$ & $\begin{array}{l}\text { Lecture- Open discussions- } \\
\text { Narration- Reinforcement- } \\
\text { Homework }\end{array}$ & $\begin{array}{c}50 \\
\text { minutes }\end{array}$ \\
\hline 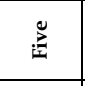 & $\begin{array}{l}\text { Reasons and factors of } \\
\text { cyberbullying }\end{array}$ & $\begin{array}{l}\text { - Define the reasons and factors of cyberbullying } \\
\text { - Educate the students about the predictors and personal } \\
\text { situations that may cause and increase cyberbullying }\end{array}$ & $\begin{array}{l}\text { Lecture- Open discussions- Cognitive } \\
\text { restructuring- Video-based therapy- } \\
\text { Reinforcement- Homework }\end{array}$ & $\begin{array}{c}5^{\circ} \\
\text { minutes }\end{array}$ \\
\hline 离 & $\begin{array}{l}\text { Enrichment information } \\
\text { about cyberbullying }\end{array}$ & $\begin{array}{l}\text { - Guide students to enhance knowledge about } \\
\text { cyberbullying by visiting specialized websites }\end{array}$ & Lecture- Open discussions- Modeling & $\begin{array}{c}5^{\circ} \\
\text { minutes }\end{array}$ \\
\hline ڤั & $\begin{array}{l}\text { Psychological aspects of } \\
\text { cyberbullying }\end{array}$ & $\begin{array}{l}\text { - Highlight the bad implications and behavioral problems } \\
\text { of cyberbullying } \\
\text { - Introduce the means of avoiding the behavioral } \\
\text { implications of cyberbullying }\end{array}$ & $\begin{array}{l}\text { Lecture- Open discussions- Roleplay- } \\
\text { Brainstorming- Thinking in high } \\
\text { voice- Reinforcement- Homework }\end{array}$ & $\begin{array}{c}5^{0} \\
\text { minutes }\end{array}$ \\
\hline 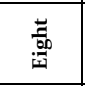 & $\begin{array}{l}\text { Social aspects of } \\
\text { cyberbullying }\end{array}$ & $\begin{array}{l}\text { - Highlight the bad social implications of cyberbullying } \\
\text { - Introduce the means of avoiding the social implications } \\
\text { of cyberbullying }\end{array}$ & \begin{tabular}{|l|} 
Lecture- Open discussions- Roleplay- \\
Brainstorming- Thinking in high \\
voice- Reinforcement- Homework
\end{tabular} & $\begin{array}{c}50 \\
\text { minutes }\end{array}$ \\
\hline$\stackrel{\mathscr{E}}{\Xi}$ & $\begin{array}{l}\text { Community aspects of } \\
\text { cyberbullying }\end{array}$ & $\begin{array}{l}\text { - Highlight the bad community implications of } \\
\text { cyberbullying } \\
\text { - Introduce the means of avoiding the community } \\
\text { implications of cyberbullying }\end{array}$ & $\begin{array}{l}\text { Lecture- Open discussions- Roleplay- } \\
\text { Brainstorming- Thinking in high } \\
\text { voice- Reinforcement- Homework }\end{array}$ & $\begin{array}{c}50 \\
\text { minutes }\end{array}$ \\
\hline$\stackrel{\Xi}{\oplus}$ & $\begin{array}{l}\text { Means of cyberbullying } \\
\text { confrontation }\end{array}$ & $\begin{array}{l}\text { - Introduce the various means of cyberbullying } \\
\text { confrontation } \\
\text { - Raise awareness of protecting personal data and files } \\
\text { online } \\
\text { - Introduce the importance of developing life skills, self- } \\
\text { expression, and making friends } \\
\text { - Raise awareness of self-esteem in the family } \\
\text { - Carry out a case study of a real situation of cyberbullying } \\
\text { - Encourage students to defend their rights through } \\
\text { discussion, self-control, and anger management }\end{array}$ & $\begin{array}{l}\text { Lecture- Open discussions- } \\
\text { Brainstorming- Thinking in high } \\
\text { voice- Reinforcement- Homework }\end{array}$ & $\begin{array}{c}5^{0} \\
\text { minutes }\end{array}$ \\
\hline$\frac{0}{\frac{2}{2}}$ & $\begin{array}{l}\text { Technical discussion of } \\
\text { relaxation and training in it }\end{array}$ & $\begin{array}{l}\text { - Raise student awareness in self-esteem and its } \\
\text { development } \\
\text { - Train students in relaxation to master self-control }\end{array}$ & \begin{tabular}{|l|} 
Lecture- Open discussions- Roleplay- \\
Relaxation- Video-based therapy- \\
Reinforcement
\end{tabular} & \begin{tabular}{|c|}
50 \\
minutes \\
\end{tabular} \\
\hline ¿ֶ̃ & $\begin{array}{l}\text { Exercises of cyberbullying } \\
\text { confrontation }\end{array}$ & $\begin{array}{l}\text { - Train in how to ask for help when experiencing } \\
\text { cyberbullying } \\
\text { - Train in the skills of making friends and building } \\
\text { positive relationships with them } \\
\text { - Train in the steps of self-expression } \\
\text { - Train in refuting irrational beliefs related to } \\
\text { cyberbullying } \\
\text { - Train in the personal talk before taking action when } \\
\text { experiencing cyberbullying } \\
\text { - Train in the feeling of being able to face difficulties and } \\
\text { taking the required behavior } \\
\text { - Train in intuition and prediction to adjust to } \\
\text { cyberbullying } \\
\text { - Train in the skills of peaceful coexistence }\end{array}$ & $\begin{array}{l}\text { Open discussions- Roleplay- } \\
\text { Modeling- self-directed talk- Assertive } \\
\text { training- Succession when } \\
\text { confronting a situation of a problem- } \\
\text { Cooperative learning- Reinforcement }\end{array}$ & $\begin{array}{l}\text { The } \\
\text { session is } \\
60 \\
\text { minutes }\end{array}$ \\
\hline 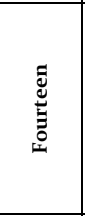 & $\begin{array}{l}\text { Means of protection } \\
\text { against the attacks of } \\
\text { hacking attacks, personal } \\
\text { accounts, and privacy } \\
\text { protection }\end{array}$ & $\begin{array}{l}\text { - Acquire the means of protecting personal accounts } \\
\text { scientifically } \\
\text { - Raise awareness of avoiding harmful software and } \\
\text { hacking attacks } \\
\text { - Introduce the means of differentiation between fake and } \\
\text { correct links } \\
\text { - Train in the safe use of the Internet } \\
\text { - Train in the means of protecting personal data }\end{array}$ & $\begin{array}{l}\text { Lecture- Open discussions- Modeling- } \\
\text { Brainstorming- Thinking in high } \\
\text { voice- Homework }\end{array}$ & $\begin{array}{c}60 \\
\text { minutes }\end{array}$ \\
\hline 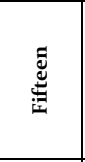 & $\begin{array}{l}\text { Using the Internet in } \\
\text { education and the role of } \\
\text { the teacher in confronting } \\
\text { cyberbullying }\end{array}$ & $\begin{array}{l}\text { - Look for the information and various knowledge } \\
\text { resources that benefit the course } \\
\text { - Highlight the importance of the Internet in enhancing } \\
\text { achievement } \\
\text { - Define the skills, objectives, and communication to } \\
\text { reduce cyberbullying }\end{array}$ & $\begin{array}{l}\text { Lecture- Open discussions- Survey- } \\
\text { Reinforcement- Homework }\end{array}$ & $\begin{array}{c}50 \\
\text { minutes }\end{array}$ \\
\hline 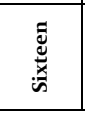 & $\begin{array}{l}\text { Family role in confronting } \\
\text { cyberbullying }\end{array}$ & $\begin{array}{l}\text { - Define the methods of sound parental treatment to } \\
\text { promote students' self-confidence } \\
\text { • Raise awareness of monitoring students and emerging } \\
\text { changes }\end{array}$ & $\begin{array}{l}\text { Lecture- Open discussions- } \\
\text { Homework }\end{array}$ & $\begin{array}{c}50 \\
\text { minutes }\end{array}$ \\
\hline
\end{tabular}




\begin{tabular}{|c|c|c|c|c|}
\hline Session & Topic & Objectives & Targeted groups & Timing \\
\hline 巳 & Concluding the program & $\begin{array}{l}\text { - Review the methods and skills of the theoretical and } \\
\text { practical confrontation of cyberbullying } \\
\text { - Evaluate learning and define and solve training } \\
\text { difficulties and problems }\end{array}$ & $\begin{array}{l}\text { Lecture- Open discussions- } \\
\text { Brainstorming- Homework }\end{array}$ & $\begin{array}{c}50 \\
\text { minutes }\end{array}$ \\
\hline 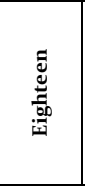 & Closing session & $\begin{array}{l}\text { - Answer all student inquiries } \\
\text { - Identify student notes and perspectives about the } \\
\text { program } \\
\text { - Identify the difficulties encountered by students in the } \\
\text { implementation of the program to be avoided } \\
\text { - Assess students in terms of advantages and } \\
\text { disadvantages }\end{array}$ & $\begin{array}{l}\text { Lecture- Open discussions- } \\
\text { Brainstorming- Homework }\end{array}$ & $\begin{array}{c}50 \\
\text { minutes }\end{array}$ \\
\hline
\end{tabular}

\section{Conclusion}

Bullying, with its aggression towards others, whether physical, verbal, social, or sexual, is one of the problems that have negative effects on the bully, the victim, and society. School bullying affects the security, psychological, and social aspects of the school community. Therefore, physical aggression with these bullies in schools harms students at any educational level as it makes the student (victim of bullying) rejected and undesirable. In addition, it makes the victim feel afraid, anxious, and uncomfortable. A victim may withdraw from participating in school activities or escaping from school for the fear of bullies. The bully may be subjected to deprivation or expulsion from the school, as well as showing inadequate benefit from the provided educational programs. Furthermore, a bully may be involved in serious criminal acts in the future.

\section{Acknowledgement}

The author would like to thank The Center for Promising Research in Social Research and Women's Studies and Deanship of Scientific Resrach at Princess Nourah bint Abdulrahman University for funding this research project No. 4133 in 2020/2021.

\section{References}

Abdelaziz, A. (2014). Aggression in high school and the role of the social worker in its treatment. Journal of Sebha University, 1(13), 170-197.

Abdul-Qadir, M. and Al-Rimawi, O. (2019). Cyberbullying and its relationship to the motivation for academic achievement among high school students of Al-Quds suburbs. International Journal of Educational and Psychological Studies, 6, 44-66.

Abu-alela, H. (2017). Effectiveness of selective counseling in reducing cyberbullying in a sample of adolescents: A counseling descriptive study. Journal of Assiut Faculty of Education, 33(6), 527-563.

Abu Allam, R. (2010). Methods of research in psychological and educational sciences ( $6^{\text {th }}$ ed.). Cairo: Dar Alnashr for Universities.

Abu Hatab, F. and Sadek, A. (2010). Methods of research and statistical analysis methods in psychological, educational, and social sciences. Cairo: The Anglo-Egyptian Bookshop.

Albentan, M. (2019). Social factors leading to bullying behavior among students in intermediate school in Hail region: A study from the perspective of the generalist practice of social work. Basic Education College Journal for Educational and Humanities Sciences, 42, 103-131.

Al-Qahtani, N. (2008). Bullying among middle school students in Riyadh: A survey study and suggestion intervention programs countermeasures that suit the environment of the school (Ph.D. dissertation). King Saud University, Saudi Arabia.

Alwan, E. (2016). Forms of bullying in the light of some demographic factors among adolescent students in Abha. Journal of Al-Azhar Faculty of Education, 35(168), 441-474.

Aly, M. (2017). A program of behavior modification to reduce bullying in a sample of primary school students (M.A. thesis). Ain-Shams University, Egypt.

American Psychological Association (2015). APA dictionary of psychology ( $2^{\text {nd }}$ ed.). USA: American Psychological Association. 
Azam, S. \& Shoba, K. (2018). A study on cyberbullying among school students in Chennai. International Journal of Pure and Applied Mathematics, 120(5), 263-273.

Bhnasawi, A. \& Hasan, R. (2015). School bullying and its relationship to academic motivation among preparatory stage students. Journal of Education in Port Said, 17, 1-40.

Burton, K., Florell, D. \& Gore, J. (2013). Differences in proactive and reactive aggression in traditional bullies and cyberbullies. Journal of Aggression, Maltreatment \& Trauma, 22(3), 316-328.

Camacho, S., Hassanein, K. \& Head, M. (2018). Cyberbullying impacts on victims- satisfaction with information and communication technologies: The role of perceived cyberbullying severity. Information $\mathcal{E}$ Management, 55(4): 494-507.

Compton, L., Campbell, M. \& Mergler, (2014). Teacher, parent and student perceptions of the motives of cyberbullies. Social Psychology of Education: An International Journal, 17(3), 383-400.

Cassidy, W. Faucher, C. \& Jackson, M. (2017). Adversity in university: Cyberbullying and its impacts on students, faculty and administrators. International Journal of Environmental Research and Public Health, 14 (888), 1-19.

Chen, J. (2018). Cyberbullying among secondary school students in Hong Kong. The Hong Kong Journal of Social Work, 52 (1): 49-62.

Darwish, A. and Allaithi, A. (2017). Effectiveness of a cognitive/ behavioral learning environment based on social preferences on developing the strategies of confronting cyberbullying among high school students. Journal of Educational Sciences, 4(1), 199-264.

Danielle, P. (2015). Cyberbullying. New York: University of Delaware.

Gamrawi, N., Gamrawi, N., and Shal, T. (2016). Teachers' perception of cyberbullying in Lebanese public schools. Open Journal of Leadership, 5(4), 95-109.

Guckin, C., Perren, S., Corcoran, L., Cowie, H., Dehue, F., Ševčíková, A...\& Völlink, T. (2013). Coping with cyberbullying: how can we prevent cyberbullying and how victims can cope with it. Retrieved from https://www.semanticscholar.org/paper/Coping-with-cyberbullying-\%3A-how-can-we-prevent-andGuckin-Perren/1161037419bazaef9749ob89aao18f5c53d30441.

Hasan, A. (2020). A selective counseling program in the service of the individual to equip the social worker with the skills of handling the incompatible behaviors related to cyberbullying. Journal of Studies on Social Work and Humanities, 2(50), 308-354.

Hashem, T. (2019). The reality and confrontation of cyberbullying among high school students in Fayoum: A field study. Journal of Fayoum University for Educational and Psychological Sciences, 12(2), 210.

Hussein, N. (2019). Effectiveness of a psychodrama-based counseling program in reducing the level of bullying among adolescents. Gaza: Al-Aqsa University.

Ibiwani, A. (2017). A study on cyberbullying: Its forms, awareness, and moral reasoning among youth. International Journal of Information and Communication Sciences, 2(58), 54-58.

Ismail, H. (2010). Some psychological variables among victims of school bullying in the elementary stage. Journal of Educational and Social Studies, 2(16), 137-170.

Johnson, L., Haralson, A., Batts, S., Brown, E., Collins, C., Buren-Travis, A. \& Spencer, M. (2016). Cyberbullying on social media among college students. VISTAS Online, 1-8.

Jun, W. (2020). A study on the cause analysis of cyberbullying in Korean adolescents. International Journal of Environmental Research and Public Health, 17(13): 4648.

Juvonen, J. \& Gross, E. (2008). Extending the school grounds? Bullying experiences in cyberspace. The Journal of School Health, 78(9), 496-505.

Khoj, H. (2012). School bullying and its relationship to social skills among the students of primary school in Jeddah, Saudi Arabia. Journal of Educational and Psychological Sciences, 4(13), 198-218.

Kiriakidis, S. and Kavoura, N. (2010). Cyberbullying: A review of the literature on harassment through the internet and other electronic means. Family E Community Health, 33(2):82-93.

Kowalski, R., Limber, S. \& Agatston, P. (2007). Cyberbullying: Bullying in the digital age. Oxford: Blackwell Publishing.

Li, Q. (2006). Cyberbullying in schools: A research of gender differences. School Psychology International, 27, 157170.

Li, Q. (2010). Cyberbullying in high schools: A study of students' behaviors and beliefs about this new phenomenon. Journal of Aggression, Maltreatment E Trauma, 19(4), 372-392.

Nazriani, D. \& Zahreni, S. (2016). Adolescent cyberbullying in Indonesia: Differentiation between bullies and victim. Advances in Social Science, Education and Humanities Research, 81, 505-508.

Makanin, H., Younis, N., \& Hayari, G. (2017). Cyberbullying in a sample of behavioral and emotional disturbed students in Zarqa. Journal of Educational and Psychological Studies, 12(1), 179-197. 
Mohamed, A. (2018). Effectiveness of a psychological enrichment-based program in improving social efficiency and reducing the level of school bullying among the bullies with learning difficulties in the primary stage. Journal of Menofia Faculty of Education, 33(2), 68-110.

Mohamed, A. and Mohamed, A. (2017). Effectiveness of a behavioral-cognitive learning environment based on social preferences in developing the strategies of cyberbullying confrontation among high school students. Educational Sciences, 1(4), 198-264.

Moses, H. T. (2013). The relationship between the processes of moral disengagement $\mathcal{E}$ youth perceptions of cyberbullying behaviors during their final semester of high school (Ph.D. dissertation). University of Florida, USA.

Mustafa, A. (2017). The role of cyberbullying among the children of the Eastern province, Saudi Arabia. Journal of Educational and Psychological Sciences, 3(18), 243-26o.

Pelfrey, W. \& Weber, N. (2014). Cyberbullying: Causes, consequences, and coping strategies. New York: LFB Scholarly Publishing.

Refaey, A. (2016). The role of the school social worker in supporting the value system to confront behavioral deviations among adolescent students via social media (Facebook): A field study in some preparatory schools in Qena. Journal of Educational Sciences, 1(4), 315-366.

Safaria, T. (2016). Prevalence and impact of cyberbullying in a sample of Indonesian junior high school students. The Turkish Online Journal of Educational Technology, 15(1), 82-91.

Selkie, E., Kota, R., Chan, Y. and Moreno, M. (2015). Cyberbullying, depression, and problem alcohol use in female college students: A multisite study. Cyberpsychology, Behavior, and Social Networking, 18(2), 79-86.

Šléglová, V., \& Cerna, A. (2011).Cyberbullying in adolescent victims: Perception and coping. Cyberpsychology: Journal of Psychosocial Research on Cyberspace, 5(2). Retrieved from https://cyberpsychology.eu/article/view/4248/3294.

Smith, P., Mahdavi, J., Carvalho, M., Russell, S. \& Tippett, N. (2008). Cyberbullying: Its nature and impact in high school pupils. Journal of Child Psychology and Psychiatry, 49(4):376-85.

Waasdorp, T., Bradshaw, C. \& Leaf, P. (2012). The impact of school-wide positive behavioural interventions and supports on bullying and peer rejection a randomized controlled effectiveness trial. The Archives of Pediatrics $\mathcal{E}$ Adolescent Medicine, 166(2):149-56. 